\title{
Evaluation of Wheat Cultivars for Slow Rusting Resistance to Leaf and Stem Rust Diseases in Egypt
}

Mabrouk, O.I.; El-Orabey, W.M. and Esmail, S.M.

Wheat Dis. Res. Dept., Plant Pathology Research Institute, Agricultural Research Center, Giza, Egypt

Teaf rust (Puccinia triticina Eriks.) and stem rust (Puccinia Lgraminis f. sp. tritici) have been considered to be the most common rust diseases of wheat. Twelve Egyptian wheat cultivars were evaluated for resistance at seedling stage using four slow rusting components i.e. incubation period, latent period, pustule density $/ \mathrm{cm}^{2}$ and pustule size $/ \mathrm{mm}^{2}$. Additionally, three parameters of slow rusting resistance at adult plant stage, rust reaction, infection response and rust severity $(\%)$. Rate of leaf and stem rust increase (r-value) and area under disease progress curves (AUDPC) were determined under artificial infection with the single race of the two fungi at the adult plant stage in greenhouse experiments. The five cultivars; Misr 3, Sids 12, Shandweel 1, Sakha 94 and Gemmeiza 12 showed low values of incubation period, pustule density $/ \mathrm{cm}^{2}$, pustules size $/ \mathrm{mm}^{2}$, infection response, r-value and AUDPC to wheat leaf and stem rust due to characterized as slow rusting resistance cultivars. Also, the cultivar Giza 168 showed complete resistance to leaf and stem rust, while, the two cultivars Misr 1 and Beni Sweif 5 showed slow rusting to leaf rust but characterized as highly susceptible and fast rusting cultivars to stem rust. Correlation between latent period and area AUDPC was negative and strong $(\mathrm{r}=0.70)$ in leaf rust but in stem rust was $(\mathrm{r}=$ 0.46). Thus, the slow rusting resistant wheat cultivars can be used for developing high-yielding with more durable resistance to leaf and stem rust diseases in bread wheat.

Keywords: Wheat, Triticum aestivum, Leaf rust, Puccinia triticina, Stem rust, Puccinia triticina, Incubation period, Latent period, Slow rusting resistance.

Wheat (Triticum aestivum L.) is the main stable sources of food in most developing countries, thereby, an important source in order to maintain food security for the growing populations in these countries. Leaf rust and stem rust of wheat are amongst the most important foliar diseases of wheat. Stem rust (Puccinia graminis $\mathrm{f}$. sp. tritici) and leaf rust (Puccinia triticina) of wheat continue to cause damage locally and globally. Stem rust occurs primarily on stem but can also be found on leaves, sheaths, glumes and owns. Wheat leaf rust is generally found on leaves. Leaf 
and stem rust cause significant and severe losses on susceptible wheat cultivars in Egypt and worldwide (Abdel-Hak et al., 1966; Ashmawy et al., 2014; Shahin and El-Orabey, 2016 and El-Orabey et al., 2017). Moreover, the detection of the wildely virulent race Ug 99 in Uganda in 1998 challenged the stem rust was a conquered disease (Singh et al., 2006 and 2008). Now, up to 90\% of world's wheat cultivars are considered stem rust susceptible (Singh et al., 2013). The high resistance to wheat rusts is primarily due to use of genetic host resistance.

Slow rusting resistance is a type of resistance that is both race-non-specific and durable (Priamvada et al., 2011). It is polygenic and effective against a broad range of wheat rust races (Herre-foessel et al., 2007). Slow rusting resistance is characterized by a slow epidemic build up despite a high infection type indicting a compatible host-pathogen relationship (Parlevliet and Van Ommeren, 1975; Priamvada et al., 2011 and Hei et al., 2014). The effectiveness of resistance in wheat cultivars to any rust disease depends on its levels, stability and durability. More attention has been drowning to alternative forms of resistance, such as, slow or nonspecific resistance to be more stable and durable. Caldwell (1968) was the first who characterized the slow rusting, partial or general resistance in cereal crops. He indicated that slow rusting retarded the rate of disease development and confers a more stable form of resistance.

The disease resistance in cereals at adult plant stage can be assessed by quantitative measurements such as severity of infection, the rate increase of epidemic and area under disease progress curve (AUDPC) at adult plant stage. While at seedling stage, the components of slow-rusting resistance can be evaluated by assessing the latent period (LP), incubation period (IP), number of pustules $/ \mathrm{cm}^{2}$ and pustules size $/ \mathrm{mm}^{2}$. The slow rusting wheat cultivars had ability to retard and delay the incidence and development of leaf and stem rust diseases conditions (Nazim et al., 1990; Negm, 2004; Boult, 2007; Mabrouk, 2012; Boult \& Ali, 2014; Fahmi et al., 2015; Mabrouk, 2016 and El-Orabey et al., 2019). Slow rusting resistance is an additional source described genes that can confer durable resistance to leaf and stem rust in bread wheat. The transfer of such resistance to commercial wheat cultivars showed contributes to long-lasting genetic control to rust diseases. Therefore, cultivation of resistant cultivars is the most effective, economic and environmentally safe control method for the farmers (Line and Chen, 1989; Chen, 2005 and El-Orabey et al., 2014).

The objective of this study was to evaluate of some Egyptian wheat cultivars for resistance to leaf and stem rust using the components and parameters of slow rusting resistance at seedling and adult plant stages under greenhouse conditions.

Egypt. J. Phytopathol., Vol. 47, No. 2 (2019) 


\section{Materials and Methods}

Twelve Egyptian wheat cultivars in addition to the two highly susceptible checks varieties Morocco and Triticum spelta saharensis (T.s.s.) (Table 1) were evaluated for slow rusting resistance to leaf and stem rust at seedling and adult plant stages under greenhouse conditions at Wheat Diseases Res. Dept., Plant pathology Res. Inst., ARC, Giza, Egypt during 2018/19 growing season.

Twenty five wheat grains from each cultivar were grown in $25 \mathrm{~cm}$ diameter pot. After germination, the plants were thinned to 10 plants per pot in randomized complete block (RCB) design. Three pots (replicates) were used for each cultivar. Artificial inoculation was carried out at booting stage ( 70 days old), as mentioned by Large (1954). Plants were dusted with the spores of single race i.e., PTTTT for leaf rust experiment and with race GFTJC for stem rust experiment, which considered more frequent and virulent according to greenhouse data analysis during this growing season which were kindly provided by Wheat Diseases Res. Dept. Plant Pathol. Res. Inst., ARC, Giza, Egypt. Spores were mixed with talcum powder at a ratio of 1: $20(\mathrm{v} / \mathrm{v})$ according to Tervet and Cassell (1951). After $24 \mathrm{~h}$ of incubation in dew chamber $(100 \%$ relative humidity) the inoculated pots were transferred to greenhouse in the other greenhouse part, where the temperature was $20 \pm 2^{\circ} \mathrm{C}$ for leaf rust greenhouse while temperature was $22 \pm 2{ }^{\circ} \mathrm{C}$ for stem rust with approximately $80 \%$ relative humidity in each greenhouse.

\section{Components of slow rusting resistance:}

Incubation period (IP), which is the number of days between inoculation to the commencement of the first pustule was estimated. Latent period (LP) was measured according to Parlevliet (1975) by counting the number of visible pustules on marked leaves daily until no more pustules appeared. From these data, time between inoculation and $50 \%$ of the pustule just visible was estimated. Number of pustules $/ \mathrm{cm}^{2}$ and the number of pustules per unit leaf area $\mathrm{cm}^{2}$ on the upper side of the leaves were counted as described by Parlevliet and Kuiper (1977). Pustule size (PS) was measured using the light microscope at $10 \mathrm{X}$ power magnification and pustules were fixed in boiled mixture of lactophenol and ethanol solution $(1: 2, \mathrm{v} / \mathrm{v})$ for three minutes. Length (L) and width (W) of 10 randomly chosen pustules per one leaf were measured following formula suggested by Broes (1989).

$$
\text { Pustule size }=1 / 4 \times \pi \mathrm{L} \times \mathrm{W}
$$

Where: $\pi=3.14$; $\mathrm{L}$ is the length; $\mathrm{W}$ is the width of each pustule. 
Table (1): Name, pedigree and year of release of fourteen wheat genotypes used in this study.

\begin{tabular}{|c|c|c|}
\hline Genotype & Pedigree & $\begin{array}{l}\text { Year of } \\
\text { Release }\end{array}$ \\
\hline Giza 168 & $\begin{array}{l}\text { MAL / BUC // SERI CM93046-8M-0Y-OM- } \\
\text { 2Y-0P }\end{array}$ & 1995 \\
\hline Giza 171 & $\begin{array}{l}\text { SAKHA 93 / GEMMEIZA 9S.6-1GZ-4GZ- } \\
\text { 1GZ-2GZ-0S }\end{array}$ & 2013 \\
\hline Misr 1 & $\begin{array}{l}\text { OASIS/SKAUZ//4*BCN/3/2*PASTORCMSS00 } \\
\text { Y01881T-050M-030Y-030M-030WGY-33M- } \\
\text { 0Y-0S }\end{array}$ & 2011 \\
\hline Misr 2 & $\begin{array}{l}\text { SKAUZ/BAV92CMSS96M03611S-1M-010SY- } \\
\text { 010M-010SY-8M-0Y-0S }\end{array}$ & 2011 \\
\hline Misr 3 & 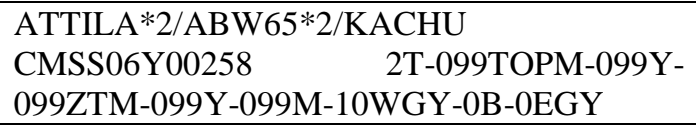 & 2019 \\
\hline Sids 12 & $\begin{array}{l}\text { BUC//7C/ALD/5/MAYA74/ON//1160.147/3/B } \\
\text { B/GLL/4/CHAT"S"/6/MAYA/VUL//CMH74A. } \\
\text { 630/4*SXSD7096-4SD-1SD-1SD-0SD }\end{array}$ & 2007 \\
\hline Sids 13 & $\begin{array}{l}\text { KAUZ'S" / TSI / SNP"S" ICW 94-0375-4AP- } \\
\text { 2AP-030AP-0APS-3AP-0APS-050AP-0AP- } \\
\text { 0SD }\end{array}$ & 2010 \\
\hline Shandweel 1 & SITE/ MO/4/NAC//3*PVN/3/MIRLO. & 2011 \\
\hline Sakha 94 & $\begin{array}{l}\text { OPATA/RAYON//KAUZCMBW90Y3180- } \\
\text { 0TOPM-3Y-010M-010M-010Y-10M-015Y-0Y-0AP-0S }\end{array}$ & 2004 \\
\hline Gemmeiza 11 & $\begin{array}{l}\text { BOW"S"/KVZ"S"//7C/SER182/3/GIZA168/SAKHA6 } \\
\text { 1GM5820-3GM-1GM-2GM-0GM }\end{array}$ & 2011 \\
\hline Gemmeiza 12 & $\begin{array}{l}\text { OTUS/3/SARA/THB//VEECMSS97Y00227S- } \\
\text { 5Y-010M-010Y-010M-2Y-1M-0Y-0GM }\end{array}$ & 2011 \\
\hline Beni Sweif 5 & $\begin{array}{l}\text { DIPPERZ/BUSHEN3.CDSS92B128-1M-0Y- } \\
\text { 3B-0Y-0SD. }\end{array}$ & 2007 \\
\hline Morocco & Susceptible check & - \\
\hline $\begin{array}{l}\text { Triticum spelta } \\
\text { saharensis (T.s.s.) }\end{array}$ & Susceptible check & - \\
\hline
\end{tabular}

2. Parameters of slow rusting resistance:

Plant response to rust infection at adult plant stage under greenhouse was termed (infection response) according to the modified Cobb's scale Peterson et al. (1948) and the reaction types by Roelfs et al. (1992) and Singh et al. (2013) (Table 2). The leaf and stem rust data were scored four times for disease severity\% (DS \%) as percentage coverage of leaves with rust pustules at weekly intervals using modified Cobb's scale (Peterson et al., 1948). Adult- plant slow rusting resistance of the each

Egypt. J. Phytopathol., Vol. 47, No. 2 (2019) 
of wheat genotypes was assessed through rust severity (\%), infection response (IR), rate of disease increase (r-value) and area under disease progress curve (AUDPC).

The final rust severity (FRS \%) was recorded as outlined by Das et al. (1993) as the disease severity (\%), when the highly susceptible check variety was severely rusted and the disease rate reached the highest and final level of rust severity. Rate of rust increase (r-value) as a function of time was also estimated using the formula adopted by Van Der Plank (1963) to determine the ability of the tested genotype to affect the development of wheat leaf and stem rust infection. Area under disease progress curves (AUDPC) was estimated to compare different responses of the tested genotypes using the equation adopted by Pandey et al. (1989).

\section{Statistical analysis:}

Data were statistically analyzed, according to Duncan's multiple range test (Duncan, 1955).

Table (2): Adult plant resistance response and severity (\%) for leaf and stem rust*.

\begin{tabular}{|c|c|c|c|}
\hline $\begin{array}{l}\text { Disease } \\
\text { response }\end{array}$ & $\begin{array}{l}\text { Disease } \\
\text { severity } \\
(\%)\end{array}$ & Host response & Symptoms \\
\hline $\mathrm{R}$ & $0-5$ & Resistant & $\begin{array}{l}\text { Resistant, no visible infection or } \\
\text { some chlorosis or necrosis and no } \\
\text { uredinia }\end{array}$ \\
\hline R-MR & $10-20$ & $\begin{array}{l}\text { Resistant to moderately } \\
\text { Resistant }\end{array}$ & \\
\hline MR & $20-30$ & Moderately Resistant & $\begin{array}{l}\text { Moderately Resistant small } \\
\text { uredinia present and surrounded } \\
\text { by either chlorotic or necrotic } \\
\text { areas }\end{array}$ \\
\hline MR-MS & $30-40$ & $\begin{array}{l}\text { Moderately Resistant to } \\
\text { Moderately Susceptible }\end{array}$ & \\
\hline MS & $40-50$ & Moderately Susceptible & $\begin{array}{l}\text { Moderately susceptible, medium- } \\
\text { sized uredinia present and } \\
\text { possibly surrounded by chlorotic } \\
\text { areas }\end{array}$ \\
\hline MS-S & $50-70$ & $\begin{array}{l}\text { Moderately Susceptible to } \\
\text { Susceptible }\end{array}$ & \\
\hline $\mathrm{S}$ & $70-100$ & Susceptible & $\begin{array}{l}\text { Susceptible, large uredinia } \\
\text { present, generally with little or no } \\
\text { chlorosis and no necrosis }\end{array}$ \\
\hline
\end{tabular}

* Based on the modified Cobb's scale (Peterson et al., 1948) and the reaction types by Roelfs et al. (1992) and Singh et al. (2013); R = Resistant; MR = Moderately resistant; MS = Moderately susceptible; $\mathrm{S}=$ Susceptible. 


\section{Results}

1. Components of slow leaf rusting resistance

Data presented in Table (3) show significant differences among the tested cultivars concerning the studied components of leaf slow rusting. Among the tested cultivars; Giza 171, Misr 1, Misr 3, Sids 13, Shandweel 1, Sakha 94 and Gemmeiza 12 exhibited the longest incubation period ranged between 12 and 15 days and the longest latent period ranged between 14 and 20 days on the basis of pustule density/ $\mathrm{cm}^{2}$ and pustule size $\mathrm{mm}^{2}$. These cultivars also exhibited the lowest values of the two components, pustule $/ \mathrm{cm}^{2}$ ranged from 1.00 to 8.66 and pustule size $\mathrm{mm}^{2}$ ranged from 0.023 to $0.085 \mathrm{~mm}^{2}$ (Table 3). Cultivars: Giza 171, Misr 1, Misr 3, Sids 13, Shandweel 1 Sakha 94 and Gemmeiza 12 could be characterized by their high levels of resistance and have slow rusting resistance to leaf rust. On contrast, cultivars; Giza 168, Misr 2 and Beni Sweif 5 were resistant where no visible infection was found and have complete resistance to wheat leaf rust. On the other hand, the Egyptian wheat cultivars Sids 12 and Gemmeiza 11 in addition to the two highly susceptible varieties Morocco and Beni Sweif 5. showed the shortest incubation and latent periods ranged from ( 8 to 12 days ) and from (9 to 15 days), respectively, these cultivars have high values of pustule density $/ \mathrm{cm}^{2}$ ranged from 21.33 to 45.00 and pustule size $/ \mathrm{mm}^{2}$ ranged from 0.076 to $0.432 \mathrm{~mm}^{2}$ and could be characterized as a highly susceptible or fast leaf rusting cultivars.

Table (3): Means of incubation period, latent period, pustule density/ $/ \mathrm{cm}^{2}$ and pustule size $/ \mathbf{m m}^{2}$ in fourteen wheat genotypes inoculated with race PTTTT of Puccinia triticina at seedling stage under greenhouse condition during 2018/19 growing season

\begin{tabular}{|c|c|c|c|c|c|}
\hline \multirow[t]{2}{*}{ No. } & \multirow[t]{2}{*}{ Genotype } & \multirow{2}{*}{$\begin{array}{l}\text { Incubation } \\
\text { period } \\
\text { (day) }\end{array}$} & \multirow{2}{*}{$\begin{array}{l}\text { Latent } \\
\text { period } \\
\text { (day) }\end{array}$} & \multirow{2}{*}{$\begin{array}{c}\text { Pustule } \\
\text { density } \\
(\mathrm{cm})^{2}\end{array}$} & $\begin{array}{l}\text { pustules size } \\
(\mathrm{mm})^{2}\end{array}$ \\
\hline & & & & & Length $\times$ Width \\
\hline 1 & Giza 171 & $12.33^{\mathrm{cd}}$ & $15.00^{\mathrm{c}}$ & $28.000^{\mathrm{b}}$ & $0.043^{\mathrm{d}}$ \\
\hline 2 & Giza 168 & $0.00^{\mathrm{h}}$ & $0.00^{\mathrm{g}}$ & $0.000^{\mathrm{d}}$ & $0.00^{\mathrm{g}}$ \\
\hline 3 & Misr 1 & $13.33^{\mathrm{bc}}$ & $20.00^{\mathrm{a}}$ & $5.000^{\mathrm{d}}$ & $0.052^{\mathrm{c}}$ \\
\hline 4 & Misr 2 & $0.00^{\mathrm{h}}$ & $0.00^{\mathrm{g}}$ & $0.000^{\mathrm{d}}$ & $0.00^{\mathrm{g}}$ \\
\hline 5 & Misr 3 & $13.00^{\text {bcd }}$ & $18.00^{b}$ & $1.000^{\mathrm{d}}$ & $0.023^{f}$ \\
\hline 6 & Sids 12 & $12.00^{\mathrm{de}}$ & $15.00^{b}$ & $43.333^{\mathrm{a}}$ & $0.076^{\mathrm{b}}$ \\
\hline 7 & Sids 13 & $14.00^{b}$ & $17.00^{b}$ & $2.000^{\mathrm{d}}$ & $0.056^{\mathrm{c}}$ \\
\hline 8 & Shandweel 1 & $15.00^{c}$ & $17.33^{\mathrm{b}}$ & $3.666^{\mathrm{d}}$ & $0.023^{f}$ \\
\hline 9 & Sakha 94 & $14.00^{\mathrm{ab}}$ & $15.00^{\mathrm{c}}$ & $6.000^{\mathrm{d}}$ & $0.052^{\mathrm{c}}$ \\
\hline 10 & Gemmeiza 11 & $11.00^{\mathrm{ef}}$ & $13.00^{\mathrm{d}}$ & $21.333^{\mathrm{bc}}$ & $0.106^{\mathrm{a}}$ \\
\hline 11 & Gemmeiza 12 & $12.00^{\mathrm{de}}$ & $14.00^{\mathrm{cd}}$ & $8.666^{\mathrm{cd}}$ & $0.085^{\mathrm{a}}$ \\
\hline 12 & Beni Sweif 5 & $0.00^{\mathrm{h}}$ & $0.00^{g}$ & $0.000^{\mathrm{d}}$ & $0.00^{\mathrm{g}}$ \\
\hline 13 & Morocco & $8.00^{\mathrm{g}}$ & $9.00^{f}$ & $45.000^{\mathrm{a}}$ & $0.335^{\mathrm{e}}$ \\
\hline 14 & T.s.s. & $9.00^{\mathrm{g}}$ & $11.00^{\mathrm{e}}$ & $27.333^{b}$ & $0.432^{\mathrm{d}}$ \\
\hline \multicolumn{2}{|c|}{ L.S.D. at $5 \%$} & 1.098 & 1.193 & 14.361 & 0.034 \\
\hline
\end{tabular}

Egypt. J. Phytopathol., Vol. 47, No. 2 (2019) 


\section{Parameters of slow-leaf rusting resistance}

On the basis of rust severity (\%) and infection response, the fourteen tested wheat cultivars were grouped into two groups of slow rusting resistance, the high and moderate levels of partial resistance having 1-30\% and 31- 50\% rust severity, respectively (Table 4). Six wheat cultivars Misr 1, Misr 3, Sids 13, Shandweel 1, Sakha 94 and Gemmeiza 12 in the first group exhibited final rust severity ranging from 1 to $20 \%$ with compatible responses (MS) and are of great importance to achieving effective breeding for durable resistance to leaf rust. The two cultivars; Misr 3 and Sids 13 displayed resistant to moderately resistant (MR) field reactions. On the other hand, cultivar Giza 171 and Gemmeiza 11were in the second group with $50 \%$ final rust severity and (MS) field response. On the other hand, the susceptible check, Morocco and T.s.s. displayed the highest disease severities of 80 and $90 \%$ with completely susceptible (S) responses, respectively. Cultivars, Giza 168, Misr 2 and Beni Sweif 5 showed immune responses.

Data in Table (4) show significant differences among the tested wheat genotypes concerning the studied parameters; r-value and AUDPC. Among the tested cultivars, Giza 171, Shandweel 1, Sakha 94 and Gemmeiza 12 showed the lowest values of rvalue ranged from 0.016 to 0.038 , while, the maximum mean of $r$-value $(0.071)$ was observed on the fast rusting cultivars Morocco and T.s.s. The three wheat cultivars; Giza 168, Misr 1 and Beni Sweif 5 showed resistance reaction (0) and constant disease severity, which showing no increase per unit time with r-value (Table 4).

The tested wheat cultivars were categorized into two distinct groups for slow rusting resistance, based on the AUDPC values. Wheat cultivars exhibiting AUDPC values less than 300 ranged from 12.00 to 220.00 having high level of partial resistance or slow rusting resistance to leaf rust, consisted of six wheat cultivars; Misr 1, Misr 3, Sids 13, Shandweel 1 Sakha 94 and Gemmeiza 12. While, cultivars; Giza 171, Sids 12, Gemmeiza 11, Morocco and T.s.s. having AUDPC values more than 300 ranged from 330.00 to 1550.00 .

A negative strong and significant correlation of latent period (LP) with area under progress curve AUDPC $(r=0.70)$ was observed between (LP) and AUDPC in the tested wheat cultivars against leaf rust (Tables 3 and 4 ).

\section{Components of slow-stem rusting resistance}

Components of wheat stem rust data indicate the presence of significant differences among the tested cultivars concerning the studied components of stem slow rusting (Table 5). Among the tested cultivars, Giza 171, Sids 12, Shandweel 1, Sakha 94, Gemmeiza 11 and Gemmeiza 12 exhibited the longest incubation period ranged between 12.00 and 21.00 days and the longest latent period ranged between 13.00 and 21.66 days. On the basis of pustule density and pustule size, these cultivars exhibited the lowest values of the two components ranged from 2.00 to 4.00 pustule $/ \mathrm{cm}^{2}$ and pustule size ranged from 2.50 to $5.26 \mathrm{~mm}^{2}$. According to stem 
slow rusting components, these cultivars; Giza 171, Sids 12, Shandweel 1, Sakha 94, Gemmeiza 11 and Gemmeiza 12 could be characterized as highly levels of slow rusting resistance to stem rust. On contrast, cultivars; Giza 168 and Sids 13 were completely resistant and no visible infection or some chlorosis or necrosis and no uredinia. On the other hand, the Egyptian wheat cultivars; Misr 1, Misr 2, Misr 3 and Beni Sweif 5 in addition, to the two highly susceptible varieties Morocco and T.s.s. showed the shortest incubation and latent periods ranged from (9.00 to 10.00 days ) and from (10.00 to 12.00 days), respectively. These cultivars have highly values of pustule density/ $\mathrm{cm}^{2}$ ranged from 4.33 to 17.33 and pustule size ranged from 6.66 to $14.66 \mathrm{~mm}^{2}$, respectively.

Table (4): Adult plant reaction (rust severity (\%) and infection response) (IR), Rate of disease increase (r-value) and area under disease progress curve (AUDPC) on fourteen wheat genotypes inoculated with race PTTTT of Puccinia triticina at adult plant stage under greenhouse condition during 2018/19 growing season.

\begin{tabular}{|c|c|c|c|c|c|}
\hline \multirow[b]{2}{*}{ No. } & \multirow[b]{2}{*}{ Genotype } & \multicolumn{2}{|c|}{ Adult plant reaction } & \multirow[b]{2}{*}{ r-value ${ }^{b}$} & \multirow[b]{2}{*}{ AUDPC } \\
\hline & & $\begin{array}{c}\text { Rust } \\
\text { severity }(\%)\end{array}$ & $\mathrm{IR}^{\mathrm{a}}$ & & \\
\hline 1 & Giza 171 & 50 & MS & $0.003^{\mathrm{e}}$ & $603.33^{\mathrm{c}}$ \\
\hline 2 & Giza 168 & 0.0 & 0 & $0.000^{\mathrm{e}}$ & $0.00^{\mathrm{k}}$ \\
\hline 3 & Misr 1 & $\mathrm{Tr}$ & MS & $0.053^{\mathrm{abc}}$ & $30.00^{\mathrm{i}}$ \\
\hline 4 & Misr 2 & 0.0 & 0 & $0.000^{\mathrm{e}}$ & $0.00^{\mathrm{k}}$ \\
\hline 5 & Misr 3 & $\mathrm{Tr}$ & MR & $0.063^{\mathrm{ab}}$ & $18.00^{\mathrm{j}}$ \\
\hline 6 & Sids 12 & 20 & $S$ & $0.076^{\mathrm{a}}$ & $230.00^{f}$ \\
\hline 7 & Sids 13 & $\operatorname{Tr}$ & MR & $0.062^{\mathrm{ab}}$ & $12.00^{\mathrm{j}}$ \\
\hline 8 & Shandweel 1 & $\mathrm{Tr}$ & $S$ & $0.023^{\text {cde }}$ & $45.00^{\mathrm{h}}$ \\
\hline 9 & Sakha 94 & 10 & MS & $0.038^{\text {bcd }}$ & $70.00^{\mathrm{g}}$ \\
\hline 10 & Gemmeiza 11 & 50 & MS & $0.003 \mathrm{e}$ & $420.00^{\mathrm{e}}$ \\
\hline 11 & Gemmeiza 12 & 20 & $\mathrm{~S}$ & $0.016^{\mathrm{de}}$ & $220.00^{\mathrm{f}}$ \\
\hline 12 & Beni Sweif 5 & 0 & 0 & $0.000^{\mathrm{e}}$ & $0.00^{\mathrm{k}}$ \\
\hline 13 & Morocco & 80 & $S$ & $0.051^{\mathrm{abcd}}$ & $1450.00^{\mathrm{b}}$ \\
\hline 14 & T.s.s. & 90 & $S$ & $0.051^{\mathrm{abcd}}$ & $1550.00^{\mathrm{a}}$ \\
\hline \multicolumn{2}{|c|}{ L.S.D. at $5 \%$} & & & 0.033 & 11.666 \\
\hline
\end{tabular}

$\mathrm{a}=$ infection response $\mathrm{b}=$ Rate of disease increase $; \mathrm{c}=$ Area under disease progress curve. 
Table (5): Means of incubation period, latent period, pustule density/cm2 and pustule size $/ \mathrm{mm}^{2}$ on fourteen wheat genotypes inoculated with race GFTJC of Puccinia graminis f. sp. tritici at seedling stage under greenhouse condition during 2018/19 growing season.

\begin{tabular}{|c|c|c|c|c|c|}
\hline \multirow[t]{2}{*}{ No. } & \multirow[t]{2}{*}{ Genotype } & \multirow{2}{*}{$\begin{array}{l}\text { Incubation } \\
\text { period } \\
\text { (day) }\end{array}$} & \multirow{2}{*}{$\begin{array}{l}\text { Latent } \\
\text { period } \\
\text { (day) }\end{array}$} & \multirow{2}{*}{$\begin{array}{l}\text { Pustule } \\
\text { density } \\
(\mathrm{cm})^{2}\end{array}$} & $\begin{array}{l}\text { pustules size } \\
(\mathrm{mm})^{2}\end{array}$ \\
\hline & & & & & Length $\times$ Width \\
\hline 1 & Giza 171 & $15.00^{b}$ & $15.33^{\mathrm{b}}$ & $4.00^{\mathrm{bcd}}$ & $5.26^{\mathrm{de}}$ \\
\hline 2 & Giza 168 & $0.00^{\mathrm{e}}$ & $0.00^{\mathrm{h}}$ & $0.00^{\mathrm{e}}$ & $0.00^{\mathrm{g}}$ \\
\hline 3 & Misr 1 & $10.00^{\mathrm{d}}$ & $10.66^{\mathrm{fg}}$ & $9.66^{\mathrm{ab}}$ & $10.00^{\mathrm{b}}$ \\
\hline 4 & Misr 2 & $10.00^{\mathrm{d}}$ & $11.66^{\mathrm{ef}}$ & $17.33^{\mathrm{a}}$ & $10.33^{b}$ \\
\hline 5 & Misr 3 & $10.00^{\mathrm{d}}$ & $11.66^{\mathrm{ef}}$ & $8.00^{\mathrm{bc}}$ & $6.66^{\mathrm{cd}}$ \\
\hline 6 & Sids 12 & $15.00^{\mathrm{b}}$ & $16.00^{\mathrm{b}}$ & $0.66^{\mathrm{cd}}$ & $3.03^{\mathrm{ef}}$ \\
\hline 7 & Sids 13 & $0.00^{\mathrm{e}}$ & 0.00 & $0.00^{\mathrm{d}}$ & $0.00^{\mathrm{g}}$ \\
\hline 8 & Shandweel 1 & $21.00^{\mathrm{a}}$ & $21.66^{\mathrm{a}}$ & $3.00^{\mathrm{bcd}}$ & $4.73^{\mathrm{de}}$ \\
\hline 9 & Sakha 94 & $15.00^{\mathrm{b}}$ & $16.33^{b}$ & $3.00^{\mathrm{bcd}}$ & $3.73^{\text {de }}$ \\
\hline 10 & Gemmeiza 11 & $12.33^{\mathrm{c}}$ & $13.00^{\mathrm{cd}}$ & $3.00^{\mathrm{bcd}}$ & $3.66^{\mathrm{de}}$ \\
\hline 11 & Gemmeiza 12 & $12.00^{\mathrm{c}}$ & $14.00^{\mathrm{c}}$ & $2.00^{\mathrm{cd}}$ & $3.00^{\mathrm{ef}}$ \\
\hline 12 & Beni Sweif 5 & $10.00^{\mathrm{d}}$ & $12.00^{\mathrm{de}}$ & $6.00^{\mathrm{bcd}}$ & $8.56^{\mathrm{bc}}$ \\
\hline 13 & Morocco & $9.00^{\mathrm{d}}$ & $11.00^{\mathrm{efg}}$ & $5.33^{\mathrm{bcd}}$ & $14.66^{\mathrm{a}}$ \\
\hline 14 & T.s.s. & $9.00^{\mathrm{d}}$ & $10.00^{\mathrm{fg}}$ & $4.33^{\mathrm{bcd}}$ & $14.00^{\mathrm{a}}$ \\
\hline & S.D. at $5 \%$ & 1.257 & 1.271 & 7.97 & 3.287 \\
\hline
\end{tabular}

4. Parameters of slow-stem rusting resistance

On the basis of stem rust severity (\%) and infection response, the tested wheat cultivars were grouped into two groups of slow stem rusting resistance, the high and moderate levels of partial resistance showed 1-30 and 31- 50\% rust severity, respectively (Table 6). Seven wheat cultivars; Giza 171, Misr 3, Sids 12, Shandweel 1, Sakha 94, Gemmeiza 11 and Gemmeiza 12 displayed disease severity values of up to $30 \%$. Two cultivars; Shandweel 1 and Sids 12 had resistant to moderately resistant (MR) reactions with rust severity less than 5\%. While, three wheat cultivars; Sakha 94, Gemmeiza 11 and Gemmeiza 12 showed moderately susceptible (MS) responses with stem rust severity ranged from 5 to $10 \%$. The two cultivars; Giza 171 and Misr 3 showed susceptible (S) responses and exhibiting final stem rust severity $10 \%$. On the other hand, cultivars; Misr 1, Misr 2, Beni Sweif 5 and the two fast rusting varieties; Morocco and T.s.s. were included in the second group and showed final stem rust severity ranged from 60 to $80 \%$ with susceptible (S) responses, while the two cultivars; Giza168 and Sids13 remained immune responses.

Data obtained in Table (6) show significant differences among the tested wheat genotypes concerning with previous parameters of slow stem rusting. Among the 
tested cultivars, Giza 171, Misr3, Sids 12, Shandweel 1, Sakha 94, Gemmeiza 11 and Gemmeiza 12 showed the lowest values of r-value ranged from 0.020 to 0.038 . While, the maximum mean of r-value ranged from 0.061 to 0.071 , was observed on the fast rusting cultivars; Misr 1, Misr 2, Morocco and T.s.s. The two cultivars; Giza 168 and Sids 13 showed a resistance (0) and constant disease severity, thus showing no increase per unit time with r-value (Table 6).

The tested wheat cultivars were categorized into two distinct groups for slow rusting resistance, based on the AUDPC values. Wheat cultivars exhibiting AUDPC values less than 300 ranged from 30.00 to 182.00 having high level of partial resistance or slow rusting resistance to stem rust, consisted of seven wheat cultivars; Giza 171, Misr 3, Sids 12, Shandweel 1, Sakha 94, Gemmeiza 11 and Gemmeiza 12. While, cultivars; Misr 1, Misr 2, Beni Sweif 5, Morocco and T.s.s. showed AUDPC values more than 300 ranged from 565.00 to 1050.00 (Table 6).

Table (6): Adult plant reaction (rust severity\%, infection response (IR) rate of disease increase ( $r$-value) and area under disease progress curve (AUDPC) on fourteen wheat genotypes inculcated with race (GFTJC) of Puccinia graminis f. sp. tritici on adult plant stage under greenhouse condition during 2018/19 growing season

\begin{tabular}{|c|c|c|c|c|c|}
\hline \multirow[b]{2}{*}{ No. } & \multirow[b]{2}{*}{ Genotype } & \multicolumn{2}{|c|}{ Adult plant reaction } & \multirow[b]{2}{*}{ r-value } & \multirow[b]{2}{*}{ AUDPC } \\
\hline & & $\begin{array}{c}\text { Rust } \\
\text { severity }(\%)\end{array}$ & $\mathrm{IR}^{\mathrm{b}}$ & & \\
\hline 1 & Giza 171 & 10 & S & 0.036 & $154.33^{\mathrm{de}}$ \\
\hline 2 & Giza 168 & 0 & 0 & 0.000 & $0.00^{f}$ \\
\hline 3 & Misr 1 & 60 & $S$ & 0.079 & $800.00^{b}$ \\
\hline 4 & Misr 2 & 60 & $S$ & 0.071 & $793.33^{b}$ \\
\hline 5 & Misr 3 & 10 & $\mathrm{~S}$ & 0.021 & $182.00^{\mathrm{d}}$ \\
\hline 6 & Sids 12 & $\operatorname{Tr}$ & MR & 0.020 & $36.00^{f}$ \\
\hline 7 & Sids 13 & 0.0 & 0 & 0.000 & 0.00 \\
\hline 8 & Shandweel 1 & $\mathrm{Tr}$ & MR & 0.020 & $30.00^{f}$ \\
\hline 9 & Sakha 94 & 5 & MS & 0.027 & $56.00^{f}$ \\
\hline 10 & Gemmeiza 11 & 10 & MS & 0.038 & $76.00^{\mathrm{ef}}$ \\
\hline 11 & Gemmeiza 12 & 5 & MS & 0.027 & $44.00^{f}$ \\
\hline 12 & Beni Swear 5 & 60 & $S$ & 0.506 & $565.00^{\mathrm{c}}$ \\
\hline 13 & Morocco & 80 & $\mathrm{~S}$ & 0.061 & $1050.00^{\mathrm{a}}$ \\
\hline 14 & T.s.s. & 60 & $\mathrm{~S}$ & 0.065 & $815.00^{b}$ \\
\hline \multicolumn{2}{|c|}{ L.S.D. at $5 \%$} & & & NS & 83.086 \\
\hline
\end{tabular}

The relationship between the two variables latent period (LP) and area under progress curve AUDPC in wheat cultivars tested against stem rust (Tables 5and 6) was negative and also correlation of (LP) with AUDPC $(r=0.46)$ was weak in these cultivars.

Egypt. J. Phytopathol., Vol. 47, No. 2 (2019) 
Data in Tables (3, 4, 5 and 6) indicate that the five cultivars; Misr 3, Sids 12, Shandweel 1, Sakha 94 and Gemmeiza 12 showed low values of incubation period, pustule density, pustules size, infection response, r-value and AUDPC to wheat leaf and stem rust characterized as slow rusting resistance cultivars. In addition, cultivar Giza 186 had complete resistance to leaf and stem rust, while the two cultivars Misr 1and Beni Sweif 5 had slow rusting to leaf rust but characterized as highly susceptible and fast rusting to stem rust. On the other hand, the cheek varieties; Morocco and T.s.s. were fast rusting to both wheat rusts.

\section{D is c us sion}

Slow-rusting in wheat to leaf rust defined by Broers (1989) is a form of incomplete, race non-specific resistance, characterized by a slow epidemic development and a retard of rust progress in the field although plants show a compatible, high infection type. It is often emphasized that partial resistance will be under polygenic control and therefore, assumed to be more durable compared to other forms of resistance conditioned by single major genes.

In the current study under greenhouse condition, four components i.e. incubation period (IP), latent period (LP), pustule density $\left(\mathrm{cm}^{2}\right)$ and pustules size $\left(\mathrm{mm}^{2}\right)$ were studied for both leaf and stem rust. In general, significant variation was found among the slow rusting resistance cultivars and the highly susceptible ones, although all of them were inoculated with the same Puccinia triticina races under favorable environmental conditions in the greenhouse. However, partial resistance character could be accurately measured and/or characterized by more of such components. Among the tested cultivars; Gemmeiza 12, Sids 13, Giza 168, Giza 171 and Sakha 94, exhibited the longest incubation period (12-14 days) and the longest (LP) (14-20 days) and have low values of pustule density and pustule size and these five cultivars could be characterized as highly level of resistance to leaf rust and considered as slow rusting cultivars. On contrast, the wheat cultivars; Sids 12 and Gemmeiza 11 in addition to the two highly susceptible varieties; Morocco and T.s.s. showed the shortest incubation and latent periods, these cultivars have highly values of pustule density and pustule size and could be characterized as a highly susceptible or fast leaf rusting cultivars (Das et al., 1993; Boulot and Ali, 2014 and Mabrouk, 2016).

According to leaf rust severity (\%) and infection response of the tested wheat cultivars, they were grouped into two groups of slow leaf rusting resistance, the high and moderate levels of partial resistance having 1-30 and more than $30 \%$ rust severity, respectively. Six wheat cultivars, Misr 1, Misr 3, Sids 13, Shandweel 1, Sakha 94 and Gemmeiza 12 are remained in the first group, exhibiting final rust severity ranging from 1 to $20 \%$ with compatible (MS) responses and are of great importance to achieving effective breeding for durable resistance to leaf rust (Parlevliet, 1988 and Nzuve et al., 2012). Previously, Ali et al. (2007); Li and Liu 
(2010); Tabassum (2011) and Safavi and Afshari (2013) also used the final rust severity to assess slow rusting behavior of wheat lines. Cultivars: Giza 168, Misr 2 and Beni Sweif 5 showed immune responses as a result of hypersensitive responses, resistance often breaks down due to the development of new races of the pathogen. A suitable breeding strategy like the use of inter-specific and remote crosses or even the direct transfer of these resistance reactions through backcrosses could be used to improve the adopted but highly susceptible wheat varieties (Bartos et al., 2002).

Among the tested cultivars, Giza 171, Shandweel 1, Sakha 94 and Gemmeiza 12 showed the lowest values of rate of disease increase (r-value) and Area under disease progress curve (AUDPC), cultivars Giza 168, Misr 1 and Beni Sweif 5 showed a constant disease severity, thus showing no increase per unit time. More variation in infection rate among the tested cultivars than the other slow rusting parameters is partially because rate of disease increase is a regression coefficient with larger error variance. Therefore, rate of disease increase in the present study seemed to produce unreliable estimates of slow rusting resistance when compared with FRS (\%) and AUDPC. Similar results were found for rusts of wheat (Rees et al., 1979; Broers, 1989; Ali et al., 2008; Safavi et al., 2010). Cultivars, Giza 171, Sids 12, Gemmeiza 11, Morocco and T.s.s. showed high values of r-value and AUDPC, these cultivars could be characterized as highly level of fast rusting resistance or susceptibility to leaf rust. According to Parlevliet (1988); Brown et al. (2001); Negm (2004); Singh et al. (2005); Kaur and Bariana (2010); Boulat et al. (2014) and Mabrouk (2016) the wheat cultivars which had MS infection type may be carrying durable resistance genes, such as slow rusting resistance. These wheat cultivars first shown rust infection and sporulation, but the final host reaction was characterized as chlorotic and necrotic lesions. Subsequently, the disease progression remained slower and highly retarded among these cultivars. Such partially resistant lines could highly delay evolution of new virulent races of the pathogen because multiple point mutations are extremely rare in normal circumstances (Schafer and Roelfs, 1985; Ali et al., 2008 and Tsilo et al., 2010). Likewise, despite the MS infection type exhibited on moderately slow rusting cultivars, leaf rust developed slowly as indicated by their AUDPC values. None of the tested cultivars was marked as having susceptible field response. Other researchers have also reported variations among different wheat lines for slow rusting resistance to leaf rust using AUDPC (Patil et al., 2005; Draz et al., 2015). Correlation between latent period (LP) with the area under disease progress curve (AUDPC) was strong and negative against leaf rust disease. These strong correlations are in agreement with the results of Qamar et al. (2007); Ali et al. (2008); Safavi et al. (2010) and Shah et al. (2010).

Among the tested cultivars, Giza-171, Sids-12, Shandweel 1 Sakha-94, Gemmeiza-11 and Gemmeiza-12 had the longest incubation period and latent period with low values of pustule density/ $\mathrm{cm}^{2}$ and pustule size $\mathrm{mm}^{2}$, these cultivars could be characterized as highly levels of slow rusting resistance to stem rust. While Egypt. J. Phytopathol., Vol. 47, No. 2 (2019) 
cultivars Giza-168 and Sids-13 were completely resistant, no visible infection or some chlorosis or necrosis and no uredia and have complete resistance to wheat stem rust. On the other hand, the Egyptian wheat cultivars Misr-1, Misr-2, Misr-3, Beni Sweif-5, Morocco and T.s.s. showed the shortest incubation and latent periods with high values of pustule density $/ \mathrm{cm}^{2}$ and pustule size $\mathrm{mm}^{2}$ which could be characterized as a highly susceptible or fast stem rusting cultivars to stem rust. The obtained results are in agreement with those reported by Singh et al. (2005); Kaur and Bariana (2010) and El-Nagar et al. (2013).

According to the studied parameters, i.e stem rust severity $\%$ and infection response, the tested wheat cultivars were grouped into two groups of slow stem rusting resistance, the high and moderate levels of partial resistance having 1-30 and more than $30 \%$ rust severity. Two cultivars; Shandweel 1 and Sids 12 had resistant to moderately resistant (MR) reactions, while three wheat cultivars; Sakha 94, Gemmeiza 11 and Gemmeiza 12 showed moderately susceptible (MS) responses and two cultivars; Giza 171 and Misr 3 showed susceptible (S) responses with final stem rust severity to all of cultivars mentioned before less than $20 \%$ which remained in the first group that characterized as a great importance to achieving effective breeding for slow stem rust resistance (Parlevliet, 1988 and Nzuve et al., 2012). The available resistance genes in these materials overcame the leaf and stem rust virulence in the field and led to statistically low disease severities despite the compatible host-pathogen reactions (Ali et al., 2007; Li and Liu 2010; Tabassum, 2011; Safavi and Afshari 2013 and Abou-Zeid et al., 2018). On the other hand, cultivars; Misr 1, Misr 2, Beni Sweif 5 and the two fast rusting varieties; Morocco and T.s.s. were included in the second group where final stem rust severity ranged from 60 to $80 \%$ with susceptible (S) responses, while, the two cultivars; Giza 168 and Sids 13 remained immune responses. Immune response on these cultivars could be as a result of hypersensitive responses. A suitable breeding strategy like the use of inter-specific and remote crosses or even the direct transfer of these resistances through backcrosses could be used to improve the adopted but highly susceptible wheat varieties (Bartos et al., 2002). Area under disease progress curve (AUDPC) is a better indicator of disease expression over time (Van der Plank, 1963). Therefore, selection of cultivars having lower AUDPC values is acceptable for practical purposes. Among the tested cultivars, Giza 171, Misr 3, Sids 12, Shandweel 1, Sakha 94, Gemmeiza 11 and Gemmeiza 12, showed the lowest values of r-value and AUDPC. These cultivars could be characterized as highly level of slow rusting resistance to stem rust (Parlevliet 1988; Nazim et al., 1990; Brown et al., 2001; Singh et al., 2005; Kaur and Bariana 2010 and El-Nagar et al., 2013). While cultivars Misr 1, Misr 2, Morocco and T.s.s. had high values of r-value and AUDPC the more variation in infection rate among the tested cultivars than the other stem slow rusting parameters is partially because rate of disease increase is a regression coefficient with larger error variance. Therefore, rate of disease increases in the present study seemed to produce unreliable estimates of slow rusting resistance 
when compared with FRS (\%) and AUDPC. Similar results were found for rusts of wheat (Rees et al., 1979; Broers, 1989; Ali et al., 2008 and Safavi et al., 2010).

The relationship between the two variables, latent period (LP) and area under disease progress curve (AUDPC) in the tested wheat cultivars against stem rust was negative weak, this indicates that the latent period (LP) was increasing, the area under the disease progress curve reduced a slowly compared with the same parameters in wheat leaf rust cultivars. This result may be due to the environmental conditions which were not available for development of stem rust disease and also plants were in physiological maturity stage healthy plant tissue was available for additional infections (Freedman and Mackenzie, 1992 and Maqsood et al., 2012).

\section{Conclusion}

Based on the present results, it is concluded that the long lasting resistance of cultivars, leaf and stem rust may be due to interactive action of the leaf rust and stem rust resistance genes carried by this cultivar. These types of gene combinations may be a good alternative for durable resistance as it behaves like horizontal resistance. Therefore, these cultivars may be useful in developing cultivars with long lasting resistance to leaf rust and stem rust diseases in Egypt.

\section{References}

Abdel-Hak, T.M.; Kamel, A.H.; Keddis, S. and Shenouda, Ikhlas, S. 1966. Epidemiology of wheat rusts in U.A.R. (Egypt). Plant Protection Department, Cereal Diseases Research Division, Technical Bulletin 1: 1- 46.

Abou-Zeid, M.A.; El-Orabey, W.M.; Omara R.I.; Mohamed, A.A. and Ashmawy, M.A. 2018. Genetic stability of wheat stem rust resistance genes under Egyptian field conditions. Egypt. J. Phytopathol., 46(1): 215-233.

Ali, S.; Jawad, S.; Shah, A. and Ibrahim, M. 2007. Assessment of wheat breeding lines for slow yellow rusting (Puccinia striformis West. tritici). Pak. J. Biol. Sci. 10: $3440-3444$.

Ali, S.; Shah, S.J.A. and Maqbool, K. 2008. Field-based assessment of partial resistance to yellow rust in wheat germplasm. J. Agric. Rural Dev. 6: 99-106.

Ashmawy, M.A.; El-Orabey, W.M.; Abu Aly, A.A. and Shahin, A.A. 2014. Losses in grain yield of some wheat cultivars infected with powdery mildew. Egypt. J. Phytopathol., 42(1):71-82.

Bartos, P., Sip V.; Chrpova, J.; Vacke, J.; Stuchlikova, E.; Blazkova, V.; Sarova, J. and Hanzalova, A. 2002. Achievements and prospects of wheat breeding for disease resistance. Czech J. Genet. Plant Breed, 38: 16- 28.

Boulot, O.A. 2007. Durable resistance for leaf rust in twelve Egyptian wheat varieties. Egypt. J. Appl. Sci., 22(7): 40-60.

Egypt. J. Phytopathol., Vol. 47, No. 2 (2019) 
Boulot, O.A. and Ali, A.A. 2014. Partial resistance of wheat (Triticum astivum) to leaf rust (Puccinia triticina) in Egypt. Egypt. J. Agric. Res., 92(3): 835-850.

Broers, L.H.M. 1989. Influence of development stage and host genotype on three components of partial resistance to wheat leaf rust in spring wheat. Euphytica, 44:187-195.

Brown, W.M.J.; Hill, J.P. and Velasco, V.R. 2001. Barley yellow rust in North America. Annu. Rev. Phytopathol. 39: 367-384.

Caldwell, R.M. 1968. Breeding for general and/or specific plant disease resistance. Third Int. Wheat Genet. Symp., pp. 263-272.

Chen, X.M. 2005. Epidemiology and control of stripe rust Puccinia striiformis f. sp. tritici on wheat. Can. J. Phytopathol. 27: 314-37.

Das, M.K.; Rajaram, S.; Ktonstad, W.K.; Mundt, C.C. and Singh, R.P. 1993. Association and genetics of three components of slow rusting in leaf rust of wheat. Euphytica, 68: 99-109.

Draz, I.S.; Abou-Elseoud, M.S.; Kamara, A.E.M.; Alaa-Eldein, O.A.E. and ElBebany, A.F. 2015. Screening of wheat genotypes for leaf rust resistance along with grain yield. Annals Agric. Sci., 60(1): 29-39.

Duncan, D.B. 1955. Multiple range and multiple F tests. Biometrics li, pp. 1-42.

EL-Naggar, D.A.; Negm, S.S.; Hermas, G.A.; Abd Elmalek, N.I. 2013. Components of slow rusting resistance to stem rust in some Egyptian wheat genotypes. Eg. J. of Appl. Sci., 28 (12B).

El-Orabey, W.M.; El-Malik, N.I.; Ashmawy, M.A. and Abou-Zeid, M.A. 2017. Reduction in grain yield caused by leaf rust infection in seven Egyptian wheat cultivars. Minufiya J. Plant Protection, 2: 71-81.

El-Orabey, W.M.; Hamweih, A. and Ahmed, S.M. 2019. Molecular markers and phenotypic characterization of adult plant resistance genes $\operatorname{Lr} 34, \mathrm{Lr} 46, \mathrm{Lr} 67$ and $\operatorname{Lr} 68$ and their association with partial resistance to leaf rust in wheat. Journal of Genetics, 98: 1-12.

El-Orabey, W.M.; Ragab, K.E. and El-Nahas, M.M. 2014. Evaluation of some bread wheat promising lines against rust diseases. Egypt. J. Phytopathol., 42(1): 83100.

Fahmi, A.I; El-Shehawi A.M. and El-Orabey W.M. 2015. Leaf rust resistance and molecular identification of $\operatorname{Lr} 34$ gene in Egyptian wheat. Journal of Microbial \& Biochemical Technology, 7(6):338-343.

Freedman, J and Mackenzie, D.R. 1992. Disease progress curves, their mathematical description and analysis to formulate predictors for loss equations. In. Teng PS

Egypt. J. Phytopathol., Vol. 47, No. 2 (2019) 
(ed) Crop loss assessment and pest management. International Book Distributing Co., Lucknow, India. pp. 37-48.

Hei, N.; Shimelsi, H.; Laing, M. and Admassu, B. 2014. Assessment of Ethiopian wheat lines for slow rusting resistance to stem rust of wheat caused by Puccinia graminis f.sp. tritici. J. Phytopathol., 163:353-363.

Herrera-Foessel, S.A.; Singh, R.P.; Huerta-Espino, J.; Crossa, J.; Djurle, A.J.; Yuen, J. 2007. Evaluation of slow rusting resistance components to leaf rust in CIMMYT durum wheats. Euphytica 155: 361-369.

Kaur, J. and Bariana, H.S. 2010. Inheritance of adult plant stripe rust resistance in wheat cultivars Kukri and Sunco. J. Plant Pathol. 92:391-394.

Large, E.C. 1954. Growth stages in cereals. Illustration of the feekes scale. Plant Path., 3: 128-129.

Li, G.Q. and Liu, D.Q. 2010. Seedling and slow rusting resistance to leaf rust in Chinese wheat cultivars. Plant Dis. 94:45-53.

Line, R.F. and Chen, X.M. 1989. Expression of stripe rust resistance genes in differential wheat cultivars. Phytopathol., 82(12):1428-1434.

Mabrouk, O.I. 2012. Studies on wheat leaf rust disease in Egypt. M.Sc. Thesis, Plant Pathology, Kafr El-Shikh Univ. 125p.

Mabrouk, O.I. 2016. Durable resistance to leaf rust in some Egyptian wheat cultivars. Ph.D. Thesis, Dept. of Plant Pathol. Fac. of Agric., Cairo Univ. 150p.

Maqsood, Q.; Dilawaz, A.G. and Muhammed, I. 2012. Determination of rust resistance gene complex Lr34/Yr18 in spring wheat and its effect on components of partial resistance. J. Phytopathology, 160: 628-636.

Nazim, M.S.; El-Shanawani, M.Z. and Boulot, O.A. 1990. Partial resistance to leaf rust in some Egyptian wheat cultivars. Proc. Of the ${ }^{6}$ th Congress of the Egyptian Phytopathology Society Part 1, pp 77-97.

Negm, S.S. 2004. Partial Resistance to Leaf Rust in Some Egyptian Wheat Varieties. Ph.D. Thesis, Fac. Agric., Minufiya Univ., 180p.

Nzuve, F.M.; Bhavani, S.; Tusiime, G.; Njau, P. and Wanyera, R. 2012. Evaluation of bread wheat for both seedling and adult plant resistance to stem rust. Afr. J. Plant Sci., 6: 426-432.

Pandey, H.N.; Menon, T.C.M. and Rao, M.V. 1989. A simple formula for calculating area under disease progress curve. Rachis, 8(2): 38-39.

Egypt. J. Phytopathol., Vol. 47, No. 2 (2019) 
Parlevliet, J.E. 1988. Strategies for the utilization of partial resistance for the control of cereal rust. In: Rajaram S; Simmonds NW. (eds) Breeding Strategies for Resistance to the Rusts of Wheat. Mexico, D.F., CIMMYT. pp. 48-62.

Parlevliet, J.E. and Van Ommeren, A. 1975. Partial resistance of barely to leaf rust, Puccinia hordei, II Relationship between field trials, micro plot tests and latent period. Euphytica, 24: 293-303.

Parlevliet, J.E. 1975. Partial resistance of barley to leaf rust, Puccinia hordei. I. Effect of cultivar and development stage on latent period. Euphytica, 24: 21-27.

Parlevliet, J.E. and Kuiper, H.J. 1977. Partial resistance of barley to leaf rust, Puccinia hordei. IV-Effect of cultivar and development stage on infection frequency. Euphytica, 26: 249-255.

Patil, V.S.; Hasabnis, S.N.; Narute, T.K.; Khot, G.G. and Kumbhar, C.T. 2005. Rusting behavior of some wheat cultivars against leaf rust under artificial epiphytotic conditions. Indian Phytopathol. 58: 221-223.

Peterson, R.F.; Campbell, A.B. and Hannah, A.E. 1948. A diagrammatic scale for estimating rust intensity on leaves and stems of cereals. Can. J. Res., 60: 496-500.

Priamvada, M.S.; Sharan, M.S. and Ratan, T. 2011. Durable resistance in wheat. Int. J. Genet. Mol. Biol., 3(8): 108-114.

Qamar, M.; Mujahid, M.Y.; Khan, M.A.; Ahmad, Z.; Kisana, N.S. and Rattu, A. 2007. Assessment of partial resistance in seven spring bread wheat genotypes to stripe rust (Puccinia striiformis) under field conditions. Sarhad J. Agric., 23: 1003-1008.

Rees, R.G.; Thomson, J.P. and Mayer, R.J. 1979. Slow rusting and tolerance to rusts in wheat 1: The progress and effect of epidemics of Puccinia grsminis tritici in selected wheat cultivars. Aust. J. Agric. Res., 30: 403-419.

Roelfs, A.P.; Singh, R.P. and Saari E.E. 1992. Rust diseases of wheat: concept and methods of disease management. CIMMYT, Mexico, D.F., 81p.

Safavi, S.A.; Ahari, A.B.; Afshari, F. and Arzanlou, M. 2010. Slow rusting resistance in 19 promising wheat lines to yellow rust in Ardabil, Iran. Pak. J. Biol. Sci., 13: 240-244.

Safavi, S.A. and Afshari, F. 2013. Virulence factors of Puccinia triticina on wheat and effectiveness of Lr genes for leaf rust resistance in Ardabil. Archives of Phytopathology and Plant Protection, 46(10): 1246-1254. 
Schafer, J.F. and Roelfs, A.P. 1985. Estimated relation between numbers of urediniospores of Puccinia graminis tritici and rates of occurrence of virulence. Phytopathology, 75: 749-750.

Shah, S.J.A.; Imtiaz, M. and Hussain, S. 2010. Phenotypic and molecular characterization of wheat for slow rusting resistance against Puccinia striiformis Westend. f.sp. tritici. J. Phytolathol., 158: 393-402.

Shahin, S.I. and El-Orabey, W.M. 2016. Assessment of grain yield losses caused by Puccinia triticina in some Egyptian wheat genotypes. Minufiya J. Agric. Res., 41(1): 29-37.

Singh, D.; Mohler, V. and Park, R.F. 2013. Discovery, characterization and mapping of wheat leaf rust resistance genes Lr 71. Euphytica, 190(10): 131-136.

Singh, R.P.; Hodson, D.P.; Huerta-Espino, J.; Jin, Y.; Njau, P.; Wanyera, R.; Herrera-Foessel, S.A. and Ward, R. 2008. Will stem rust destroy the world's wheat crop?. Adv. Agron., 98:271-309.

Singh, R.P.; Hodson, D.P.; Jin, Y.; Huerta-Espino, J.; Kinyua, M.G.; Wanyera, R.; Njau, P.; and Ward, R.W. 2006. CAB Reviews: Perspectives in Agriculture, Veterinary Science, Nutrition and Natural Resources, 1, No. 054.

Singh, R.P.; Huerta-Espino, J. and William, H.M. 2005 Genetics and breeding of durable resistance to leaf and stripe rusts in wheat. Turkish J. Agric. Forestry, 29: 121-127.

Tabassum, S. 2011. Evaluation of advance wheat lines for slow yellow rusting (Puccinia striiformis f. sp. tritici). J. Agric. Sci., 3:239-249.

Tervet, I. and Cassell, R.C. 1951. The use of cyclone separation in race identification of cereal rusts. Phytopathology, 41: 282-285.

Tsilo, T.J.; Jin, Y. and Anderson, J.A. 2010. Identification of Flanking Markers for the stem rust resistance gene Sr6 in Wheat. Crop Sci., 50: 1967-1970.

Van der Plank, T.E. 1963. Plant Diseases. Epidemics and Control. Academic Press. New York, 349pp.

Corresponding author: Mabrouk, O.I.

E-mail: ola_pathology@yahoo.com

(Received 06/08/2019;

in revised form 03/09/2019)

Egypt. J. Phytopathol., Vol. 47, No. 2 (2019) 


\title{
تقييم أصناف القمح للمقاومة بتبطيء الصدأ لمرضي

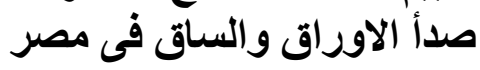

\author{
علا ابراهيم مبروك ، وليد محما العرابى ،و سمر محما إسماعيل

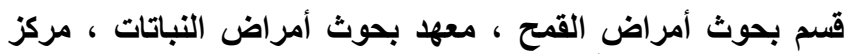

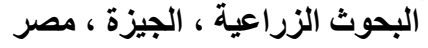

تعتبر أصداء القمح سواء صدأ الاوراق (Puccinia triticina Eriks.) أو أو صدأ الساق

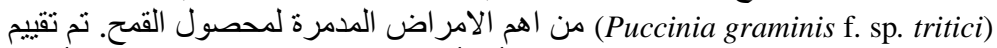

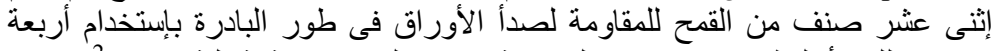

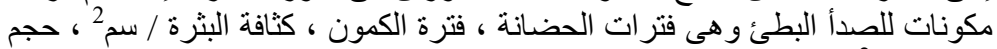

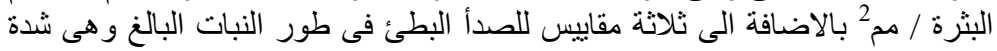

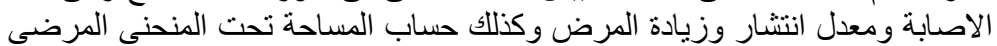

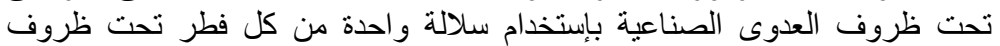

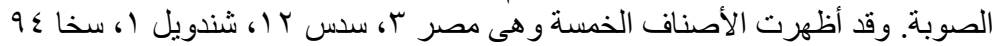

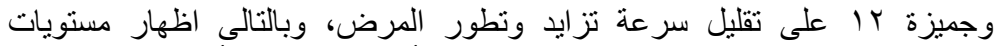

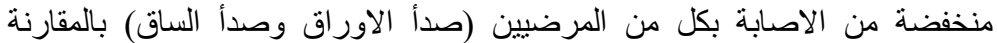

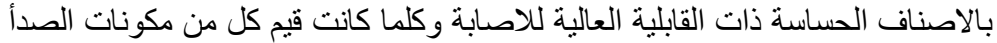

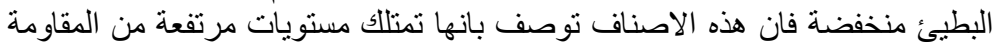

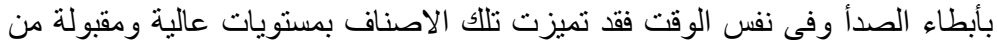

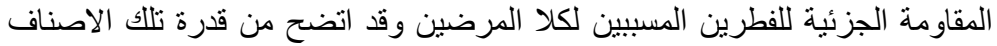

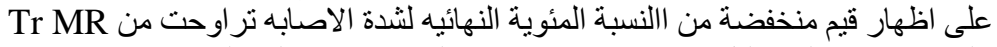

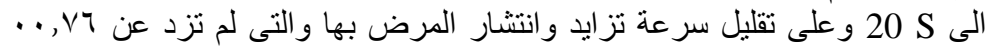

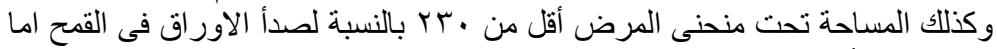

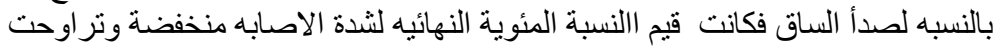

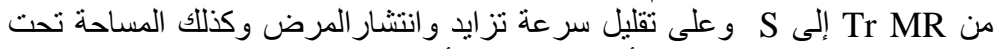

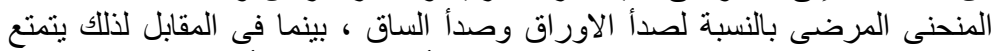

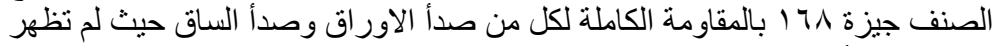

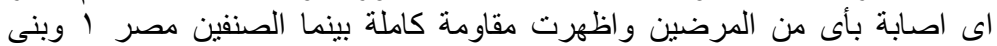

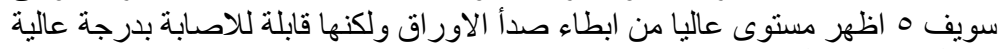

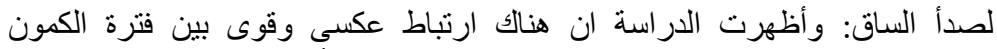

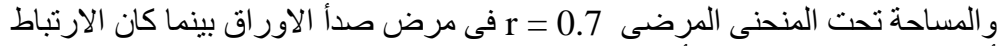

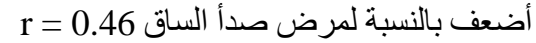

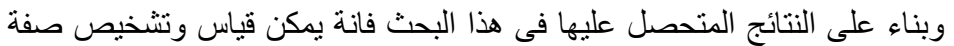

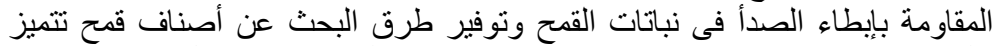

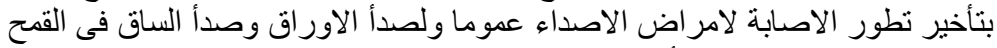

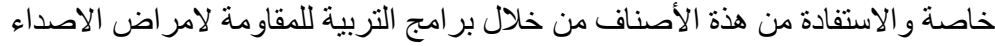

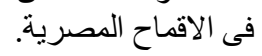

